This constant temperature of the surface having been once established, the internal parts would be hotter than the crust, and their heat must then necessarily, by the law of conduction, pass from the hotter to the cooler region, and so into and through the crust, and be radiated away from the surface into space, the kind of action which I illustrated in my former letter by the dispersion of a crowd. Thus the interior, would tend to fall to the already established temperature of the surface, and thenceforth tend to cool more rapidly than the "crust." For the nearer a stratum lies to the surface, the less cooling will be requisite to bring it down to the temperature of the surface. To take the extreme case ; after the lapse of an infinite time the whole globe would eventually become of the temperature which the surface assumed at that already far-distant epoch, and has maintained ever since.

When the superficial strata had early assumed their nearly permanent temperature, they will concomitantly have attained a corresponding permanent volume, which will afterwards have 1 roved too large for the cooling interior, so that they must, in subsiding, have become wrinkled. To this extent, then, I think Mr. Wallace's objections are untenable. Here, however, enters the question, so difficult to answer in nearly all geological problems, of "How much?" For my part, I think I have proved that the mere cooling, though a vera causa, would not be of itself a sufficient cause to account for the inequalities existing now, at what must be, judging by the enormous store of heat still within the earth, a comparatively early stage of the cooling. ${ }^{1}$

Harlton, Cambridge, January 18

\section{Leibnitz's Mathematics}

IN NATURE, vol. xix. p. 196, I see there is a letter respecting the claims of Newton and Leibnitz to the discovery of the differential calculus. In view of any future discussion of this matter it seems to me that the following extract from a letter of Leibnitz to James Bernoulli is worth the consideration of the advocates of both claimants :-

"Ego qui semper hoc habui eximium, ut' essem mortalium docillimus, sapeque luce ex unius magni viri verbis pauculis hausta innumera mea meditata nondum matura delevi ; statim arripere monita summi mathematici."-Ex epistola Leibnitii ad Jac. Bernoullium, A pril, r7o3, data.

The sense of this pas:age may, I think, be fairly rendered into English as follows :-

"I [am one] who ever regarded this as most important, that I shon!d be most apt of mortals to receive instruction, and frequently light having been drawn from a very few words of a great man, my countless meditations not yet ripened I have blotted out forthwith to seize upon the hints of the most eminent mathematician."

Lower Bronghton, near Manchester, January ${ }_{3} 3$

I HOLD myself prepared to make good my own assertions, and to respond to Mr. A. B. Nelson's call as soon as I know whether Prof. Tait has abandoned his position, or, if not, what he has to say in justification of his proceeding in denying Leibnitz to be a mathematician and affirming him to be a thief.

I am sure the eaitor will allow me to reply to his postscript. It is certainly not to be presumed, as a matter of course, that when Prof. Tait "lets pass such a challenge he has given up his point." But I do insist upon it that this "hard-worked scientist" had no right to pass it by after having provoked it. He put himself in the wrong, and I left him there.

But as to this being a question of merely "antiquarian interest," I take leave to deny it. I revere the name and intellect of Leibnitz, and I, for one, have a human interest in clearing that name from a foul slander. Nor should we pass by the main issue to discuss the collateral question which the editor raises in respect of Gregory's series.

C. M. INGLEBY

Valentines, Ilford

\section{German Degrees}

IT having come to the certain knowledge of the Faculty of Philosophy in the University of Erlangen that a fraudulent trade is carried on in England under a pretence of procuring doctor diplomas of the said Faculty, I consider it in the interest of the public hereby to make it known that promotions in absentia are not conferred in that faculty, and that no one in England, or elsewhere, is, or has ever been, authorised to confer or negotiate for the conferring of such diplomas.

\section{E. LOMMEL,}

Dean of the Faculty of Philosophy,

Erlangen, January 14 University of Erlangen, Bavaria

\section{Feeding a Python}

THE following details of a recent attempt to feed a python now at the Raffles Museum, Singapore, may be of interest as upsetting previous ideas as to the certainty of that reptile's attack :-

The python in question is a fine specimen caught on the island, for the sake of the reward given by the police in such cases, and measures about 22 feet in length. It has been in my charge for about two and a half months, during which time it has not been fed. About ten days since it commenced casting its skin, and, as is usual after that proceeding, was unusually lively, snapping at a stick put into the cage, and in one or two instances narrowly missing the attendant's hand. The reptile, I should mention, escaped from its cage just before casting, but having taken refuge beneath some odds and ends of timber near the museum, was recaptured without difficulty, and was then placed in a cage about 5 feet square every way.

A pariah dog having been obtained, it was introduced, muzzled, into the cage, the muzzle being then slipped. While entering, the snake struck twice at the dog's hind-quarters, but without seizing it. The dog crept into a corner and sat down. Two or three more blows were then made by the snake, but, as before, without gripping, and the dog was then seen to have been struck by the teeth on the fore-quarters, the punctures slightly bleeding. For nine successive times the snake struck at the dog with the same ill-success, and as it was then growing dark, the shutter of the cage was closed. Early next morning the snake was found coiled round the dog, which it had killed and commenced to swallow; but a Malay attendant having touched the python with a rod, it untwined itself and retreated to a corner of the cage, refusing to again touch its prey.

I may be misinformed, but have always understood that snakes of the python or boa tribe seldom renew their attacks if the first fails; and I shall be glad if you can direct me to any published experience on the subject. The python in question is a male.

Singapore, November $25,1878 \quad$ N. B. D.

\section{Shakespeare's Colour Names}

I FEAR it would be somewhat rash to convict Shakespeare of colour-blindness, or even vagueness in the use of colour-names, solely on the evidence of the Nurse in "Romeo and Juliet"-a lady who is the Mrs. Malaprop of the play, and whose extraordinary faculty for the confusion of terms may perhaps have contributed somewhat to the "merriness" with which she credited her husband. It is possible that the Nurse-in the passage quoted hy Mr. J. J. Murphy (NATURe, vol. xix. p. 197)-meant to convey the idea of a hazel eye, which would not be far removed in colour from that of an eagle, but also often has a slight tendency to a greenish hue. The nurse, not being particular as to the precision of her descriptions in general, refers to it as green.

It is likely besides that Shakespeare deliberately intended the incongruity, just as in the "Midsummer Night's Dream" he makes the bumplin who acts Thisbe in that piece of "very tragical mirth," Pyramus and Thisbe, lament

$$
\begin{aligned}
& \text { "Those lily brows, } \\
& \text { This cherry nose, } \\
& \text { These yellow cowslip cheeks, } \\
& \text { His eyes avere green as lecks." }
\end{aligned}
$$

This passage indeed shows that Shakespeare knew perfectly well the chromatic meaning of green.

A very cursory glance through Shakespeare will show innumerable lines where colours are referred to in their true and exact sense.

Here are a few passages selected with special reference to the colours green and blue.

Prospero's description of the witch Sycorax :-

"This blue-eyed hag."-Tempest, i. sc. 2

(The :derl Candivarian witch.) 